University of Nebraska - Lincoln

DigitalCommons@University of Nebraska - Lincoln

1998

\title{
Forage Yield and Quality of Tall Wheatgrass Accessions in the USDA Germplasm Collection
}

\author{
Kenneth P. Vogel \\ University of Nebraska-Lincoln, kvogel1@unl.edu \\ Kenneth J. Moore \\ lowa State University
}

Follow this and additional works at: https://digitalcommons.unl.edu/usdaarsfacpub

Vogel, Kenneth P. and Moore, Kenneth J., "Forage Yield and Quality of Tall Wheatgrass Accessions in the USDA Germplasm Collection" (1998). Publications from USDA-ARS / UNL Faculty. 1922.

https://digitalcommons.unl.edu/usdaarsfacpub/1922

This Article is brought to you for free and open access by the U.S. Department of Agriculture: Agricultural Research Service, Lincoln, Nebraska at DigitalCommons@University of Nebraska - Lincoln. It has been accepted for inclusion in Publications from USDA-ARS / UNL Faculty by an authorized administrator of DigitalCommons@University of Nebraska - Lincoln. 


\title{
Forage Yield and Quality of Tall Wheatgrass Accessions in the USDA Germplasm Collection
}

\author{
Kenneth P. Vogel* and Kenneth J. Moore
}

\begin{abstract}
Tall wheatgrass [Thinopyrum ponticum (Podp.) Liu and Wang] is a cool-season bunchgrass from southern Europe and Asia Minor that is tolerant to saline or alkaline soils. The genetic base of tall wheatgrass cultivars is narrow. The lineages of four of the six cultivars of tall wheatgrass developed and released in the USA and Canada trace to a common accession, PI 98526 . The objective of this study was to determine the extent of variation in the USDA collection of tall wheatgrass for forage quality, yield, and other agronomic traits. All available accessions of tall wheatgrass $(n=50)$ from the USDA Western Regional Plant Introduction Station at Pullman, WA, and two check cultivars, Platte and Jose, were used in the study. Greenhouse grown seedlings were transplanted in 1989 into a replicated field evaluation nursery located about $35 \mathrm{~km}$ west of Omaha, NE. An evaluation plot consisted of a single row of 10 plants spaced on 1.1-m centers. The experimental design was a blocks-in-replicates design with two replications. The plots were evaluated for forage yield and quality including in vitro dry matter digestibility (IVDMD), protein content, and other traits in 1990 and 1991. Several of the PI lines had forage yields equivalent to the check cultivars. One accession, PI 98526, had higher first harvest IVDMD than the check cultivars; other accessions had IVDMD values equivalent to the check cultivars. In addition to having high yields and high IVDMD, these accessions also were equivalent to the check cultivars in other agronomic traits as indicated by high leafiness and inflorescence scores. The results indicate that superior germplasm exists in the USDA tall wheatgrass germplasm collection that can be used to develop improved cultivars of tall wheatgrass with improved forage quality as measured by IVDMD.
\end{abstract}

$T_{1}$ ALL WhEaTGrass, [Thinopyrum ponticum (Podp.) Liu and Wang] (Asay and Jensen, 1996) or Elytrigia elongata (Host) Nevski (Alderson and Sharp, 1994), is a perennial, decaploid $(2 n=70)$ cool-season bunchgrass from southern Europe and Asia Minor where its habitat includes areas with saline or alkaline soils (Asay and

K.P. Vogel, USDA-ARS, Wheat, Sorghum, and Forage Research Unit, 344 Keim Hall, Dep. of Agronomy, Univ. of Nebraska, P.O. Box 830937, Lincoln, NE; K.J. Moore, Dep. of Agronomy, Iowa State Univ. Ames, IA. Journal Series No. 11852, Nebraska Agric. Exp. Stn. Received March 31, 1997. *Corresponding author (agro012@ unlvm.unl.edu).

Published in Crop Sci. 38:509-512 (1998).
Jensen, 1996). Depending on authority, it is also known as Agropyron elongatum spp. ruthenicum Beldie and A. elongatum (Host) Beauv. in North America. A diploid, T. elongatum (Host) D.R. Dewey, which also was previously known as $A$. elongatum and which also had the common name of tall wheatgrass is now recognized as a separate species (Zhang et al., 1996). In this paper the name "tall wheatgrass" refers to $T$. ponticum.

Tall wheatgrass is highly tolerant of saline or alkaline soils and it is used in the western half of the USA for revegetating saline or alkaline areas (Asay and Jensen, 1996). Although it produces more forage than most wheatgrasses when grown on fertile soils, its forage is coarser and less palatable than forage of other wheatgrasses (Asay and Jensen, 1996). Tall wheatgrass was evaluated in a grazing trial for 3 yr (1957-1959) in eastern Nebraska by Conard and Clanton (1963) where it produced beef cattle (Bos taurus) gains per day and gain per hectare that were equivalent to intermediate wheatgrass [Thinopyrum intermedium (Host)] (Barkworth and Dewey, 1985) and smooth bromegrass [Bromus inermis Leyss.]. However, electrical fencing was required to keep the cattle inside the tall wheatgrass pastures (E.C. Conard, 1975, personal communication). In a grazing trial with dairy cows at North Platte, NE, in which smooth bromegrass, intermediate wheatgrass, and tall wheatgrass were compared, milk production per cow was similar for all three grasses (Rumery et al., 1964), but the tall wheatgrass pastures produced less milk per ha. Rumery et al. (1964) noted that when given free choice, cows preferred intermediate wheatgrass and bromegrass over tall wheatgrass.

Six cultivars of tall wheatgrass have been developed and released (Alderson and Sharp, 1994) in the USA and Canada. Four of the six cultivars, Alkar, Nebraska 98526, Orbit, and Platte, were all derived from PI 98526 , which was presented to the USDA by N.I. Vavilov in 1932 (Alderson and Sharp, 1994). Alkar was developed by mass selection at the USDA-SCS (now NRCS) Plant Materials Center, Pullman, WA, and released in 1951.

Abbreviations: IVDMD, in vitro dry matter digestibility. 
Nebraska 98526 was produced by direct release to seed growers without selection. It was first certified by the Nebraska Crop Improvement Association in 1950. Platte, which was released in 1972, was developed by the cooperative USDA-ARS and University of Nebraska grass breeding program at Lincoln, NE, by several generations of intermating and selection of two sources of tall wheatgrass, one of which was PI 98526 and the other was of unknown origin. Orbit was developed and released in 1966 at Swift Current, Saskatchewan, from PI 98526 by breeding for winter survival, and seed and forage yield. 'Jose' was developed from accession PI 150123 by mass increase, accompanied by roguing atypical plants. 'Largo' was developed by bulk increase of PI 109452. Both Jose and Largo were developed at the former USDA-SCS nursery at Albuquerque, NM. The cultivar Tyrrell was developed in Australia from Largo for improved tolerance to saline conditions (Asay and Jensen, 1996). None of the cultivars were selected or evaluated for improved forage quality or palatability.

The objective of this study was to determine the genetic variation in the USDA collection of tall wheatgrass germplasm for agronomic traits, including forage digestibility and protein content, which would be available for improving the forage quality and yield of tall wheatgrass by breeding.

\section{MATERIALS AND METHODS}

Seed of all available accessions $(n=50)$ of tall wheatgrass was obtained from the USDA Western Regional Plant Introduction Station at Pullman, WA. Two check cultivars, Platte and Jose, were included in the study. The accessions were planted on 24 March 1989 into plastic seedling tubes $(22 \mathrm{~cm}$ deep, 4-cm diam.) which contained a mixture of $2: 1: 1$ soil/ peat/ vermiculite $(\mathrm{v} / \mathrm{v} / \mathrm{v})$ and were thinned to one seedling per tube after emergence. The seedlings were transplanted on 9 June 1989 into the field evaluation nursery located at the Univ. of Nebraska Agricultural Research and Development Center, Mead, NE, which is located about $35 \mathrm{~km}$ west of Omaha, NE. The soil type was Sharpsburg silt loam (silty clay Typic Argiudoll). An evaluation plot consisted of a single row of 10 plants spaced on $1.1-\mathrm{m}$ centers. The experimental design was a blocks-in-replicates design (Schutz and Cockerham, 1966) with two replicates. Previous research evaluating Agropyron, Thinopyrum, and Bromus perennial grass germplasm accessions in the central Great Plains demonstrated that a small number of replicates harvested for more than one year provided adequate statistical precision (Lamb et al., 1984; Vogel 1980, 1983; Vogel et al., 1986). The 50 accessions were arbitrarily assigned to four blocks of eight accessions and two blocks of nine accessions. The two check cultivars were included in each block. The blocks were randomized within replicates and accessions were randomized within blocks. The nursery was maintained as a space-transplanted nursery throughout the study by roto-tilling between rows and plants within rows.

Tillage, hoeing, and herbicides were used for weed control. In $1989,2 \mathrm{~kg} \mathrm{ha}^{-1}$ metolachlor [2-chloro- $N$-(2-ethyl-6-methylphenyl)- $N$-(2-methoxy-1-methylethyl)acetamide] and $22 \mathrm{~g}$ $\mathrm{ha}^{-1}$ chlorsulfuron [2-chloro- $N$-[[4-methoxy-6-methyl-1,3,5,triazin-2-yl)-aminocarbonyl]benzene-sulfonamide]] were applied after transplanting. In 1991, the same herbicides were applied at the same rates on 9 April. In 1990, $2.2 \mathrm{~kg} \mathrm{ha}^{-1}$ alachlor 2-chloro-2',6'-diethy- $N$-(methoxymethyl)acetanilide] and $22 \mathrm{~g} \mathrm{ha}^{-1}$ chlorosulfuron were applied on 17 April. The herbicide 2,4-D (2,4-dichlorophenoxyacetic acid) was applied on 9 June 1989 and 17 April 1990 at a rate of $0.3 \mathrm{~kg}$ $\mathrm{ha}^{-1}$. Nitrogen fertilizer was not applied the establishment year. In $1990,90 \mathrm{~kg} \mathrm{~N} \mathrm{ha}^{-1}\left(\mathrm{NH}_{4} \mathrm{NO}_{3}\right)$ was applied on $18 \mathrm{April}$ and $45 \mathrm{~kg} \mathrm{~N}^{-1}$ was applied on 10 September. In 1991, $100 \mathrm{~kg} \mathrm{~N} \mathrm{ha}^{-1}\left(\mathrm{NH}_{4} \mathrm{NO}_{3}\right)$ was applied on 26 April. No other fertilizers were used. Soil tests indicated $P$ and $K$ levels were adequate.

In 1990 and 1991, the first forage harvest of the year (H1) was on 18 and $16 \mathrm{July}$, respectively, on a plot basis after all plants had headed. In 1990, the second forage harvest $(\mathrm{H} 2)$ of regrowth was on 18 October. Plots were harvested at a height of approximately $10 \mathrm{~cm}$ with a flail plot harvester. Prior to harvest, the plots were sampled by collecting three to four tillers at a height of $10 \mathrm{~cm}$ from each plant within a plot. The samples were dried in a forced draft oven at $50^{\circ} \mathrm{C}$ to determine dry matter concentration of the harvested forage, which was used to convert fresh weight yields to a dry weight basis. Because some seedlings did not survive the establishment year, yields were expressed on a single-plant basis by adding sample dry weight to plot dry weight and dividing that total by the number of plants harvested per plot.

The forage samples collected for dry matter determination were used for forage quality analyses. The dried samples were ground in a Wiley ${ }^{1}$ shear mill to pass a $1.0-\mathrm{mm}$ screen and then reground to uniformity in a cyclone impact mill with a $1.0-\mathrm{mm}$ screen. Forage samples were analyzed to determine in vitro dry matter digestibility (IVDMD) and crude protein concentration (CP) on a dry-weight basis by near infrared reflectance spectroscopy (NIRS) using the protocol described by Windham et al. (1989). All ground samples were scanned with a NIRS unit (Technicon Infralyzer 500, Bran \& Luebbe Analyzing Technologies, Buffalo Grove, IL) over a wavelength range of 1100 to $2500 \mathrm{~nm}$ with $2-\mathrm{nm}$ steps. A subset of samples used to develop the prediction equations were analyzed for IVDMD by means of the procedure of Marten and Barnes (1980). Rumen fluid for the IVDMD analyses was collected and bulked from two cannulated steers (Bos taurus), one being maintained on a diet of alfalfa (Medicago sativa L.) and the other on a diet of corn cobs (Zea mays L.). Crude protein concentration was determined by Kjeldahl procedures (AOAC, 1980). Coefficients of determination and standard errors for calibration and prediction were $0.90,36.4$, and 24.4, respectively, for IVDMD $\left(\mathrm{g} \mathrm{kg}^{-1}\right)$ and $0.99,6.5$, and 5.8 for crude protein $\left(\mathrm{g} \mathrm{kg}^{-1}\right)$.

Plant leafiness and inflorescence number scores were recorded in 1991 and 1992 on a 1 -to-9 scale with $1=$ very poor and $9=$ excellent. In 1992, heading date information also was recorded as day of the year. A selection index (NI or Nebraska Index), which weights forage yield and forage IVDMD equally, was calculated using first harvest (H1) yield and IVDMD as NI = (yield - nursery mean yield)/ yield SD) + (IVDMD - nursery mean IVDMD)/ IVDMD SD) in which SD is the overall experiment standard deviation. The NI values were determined for each year and then averaged over years.

Analysis of variance (ANOVA) procedures were used to assess the statistical significance of variation among germplasm accessions (Steel and Torrie, 1980). A blocks-in-replicates ANOVA was conducted using plot means averaged over years. An average error variance was calculated using procedures described by Shutz and Cockerham (1986) for a blocksin-replicates design. The average error variance was used to

Names of products are included for the benefit of the reader and do not imply endorsement by the USDA or the Univ. of Nebraska. 
Table 1. Means and other statistics for agronomic traits for tall wheatgrass check cultivars and accessions from the USDA germplasm collection evaluated at Mead, NE, in 1990, 1991, and 1992. Only accessions with NI values greater than 1.0 are listed.

\begin{tabular}{|c|c|c|c|c|c|c|c|c|c|c|c|}
\hline Accession & Yield H1 $\dagger$ & IVDMD H1 $\dagger$ & $\mathbf{N I} \dagger$ & $\begin{array}{l}\text { Protein } \\
\text { H1 } \dagger\end{array}$ & $\begin{array}{c}\text { Heading } \\
\text { date } \neq\end{array}$ & Height & $\begin{array}{l}\text { Yield } \\
\text { H2§ }\end{array}$ & $\begin{array}{c}\text { IVDMD } \\
\text { H2§ }\end{array}$ & Protein $\mathrm{H} 2 \$$ & $\begin{array}{l}\text { Leafiness } \\
\text { score Il }\end{array}$ & $\begin{array}{c}\text { Inflorescence } \\
\text { score }\end{array}$ \\
\hline & g plant ${ }^{-1}$ & $\mathbf{g ~ k g}^{-1}$ & & $\mathbf{g} \mathbf{k g}^{-1}$ & d & $\mathbf{c m}$ & g plant ${ }^{-1}$ & 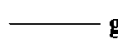 & $\mathbf{k g}^{-1}$ & 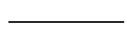 & $1-9$ \\
\hline Jose & 394 & 474 & 0.79 & 76 & 171 & 125 & 110 & 692 & 229 & 5.8 & 5.8 \\
\hline Platte & 458 & 500 & 2.21 & 71 & 173 & 121 & 91 & 677 & 226 & 6.5 & 7.0 \\
\hline PI 98526 & 423 & 548 & $\mathbf{3 . 5 3}$ & 66 & 173 & 115 & 59 & 722 & 223 & 6.0 & 6.3 \\
\hline PI 238222 & 357 & 511 & 1.76 & 99 & 162 & 114 & 104 & 689 & 252 & 5.5 & 5.0 \\
\hline PI 264770 & 463 & 502 & 2.34 & 86 & 164 & 115 & 72 & 694 & 233 & 6.8 & 7.0 \\
\hline PI 283163 & 461 & 488 & 1.79 & 105 & 163 & 113 & 71 & 716 & 271 & 6.8 & $\mathbf{5 . 3}$ \\
\hline PI 283164 & 385 & 489 & 1.34 & 78 & 167 & 111 & 83 & 681 & 222 & 5.8 & 5.3 \\
\hline PI 368851 & 351 & 514 & 1.75 & 71 & 177 & 114 & 64 & 651 & 233 & 5.2 & 5.8 \\
\hline PI 401006 & 480 & 497 & 2.36 & 82 & 173 & 129 & 133 & 654 & 228 & 6.0 & 6.2 \\
\hline PI 401007 & 349 & 493 & 1.29 & 84 & 173 & 128 & 140 & 714 & 241 & 5.5 & 6.8 \\
\hline PI 469212 & 416 & 476 & 1.08 & 93 & 162 & 120 & 75 & 681 & 251 & 6.3 & 6.3 \\
\hline Mean & 296 & 478 & 0 & 81 & 170 & 117 & 74 & 673 & 231 & 5.2 & 5.7 \\
\hline Minimum & 94 & 418 & -2.8 & 66 & 162 & 86 & 15 & 576 & 208 & 3.5 & 4.3 \\
\hline Maximum & 480 & 548 & 3.5 & 110 & 179 & 138 & 140 & 722 & 263 & 6.3 & 7 \\
\hline F ratio & $4.2 * *$ & $3.6^{* *}$ & & $3.4^{* *}$ & $3.1 * *$ & $1.8 *$ & $3.4 * *$ & 1.4 & $2.06^{* *}$ & $4.1 * *$ & $4.6^{* *}$ \\
\hline LSD 0.05 & 128 & 33 & & 12 & 6 & 16 & 38 & NS & 18 & 1 & 1 \\
\hline CV \% & 27 & 4 & & 10 & 2 & 9 & 32 & 4 & 5 & 13 & 11 \\
\hline
\end{tabular}

$*, * * *=$ indicate significance at the 0.05 and 0.01 levels of probability, respectively.

$\dagger$ NI = Nebraska Index for weighting plants for IVDMD and yield; H1 yields, IVDMD, and protein are from 1990 and 1991 . IVDMD is in vitro dry matter digestibility, $\mathrm{H1}$ is first-cut harvest, $\mathrm{H} 2$ is regrowth harvest.

$\$$ Heading dates are days after 1 January for 1992 .

\$ Second harvest (H2) forage yields, IVDMD, and protein were determined only in 1990.

II Scoring system for all rating data: $1=$ very poor to $9=$ excellent.

calculate LSD values for each trait where the $F$ test for accessions or strains was significant at the 0.05 probability level. Means over years were used because average performance of a perennial over years is the most important indicator of agronomic value, and in previous perennial grass germplasm evaluation research, accession $\times$ year interaction effects were either not significant or small (Lamb et al., 1984; Vogel, 1983; Vogel et al., 1986). Phenotypic correlations were determined with accession means averaged over years.

\section{RESULTS AND DISCUSSION}

Significant differences were found among accessions for all traits except for regrowth IVDMD (Table 1) and regrowth dry matter concentration (data not shown). Several accessions including PI 98526 had forage yields equivalent to the yields of the check cultivars, Jose and Platte (Table 1). PI 98526 had higher first harvest IVDMD than the cultivars or other accessions. It also had the highest second harvest IVDMD, although the differences were not statistically significant. The $\mathrm{Ne}$ braska Index (NI) values can be used to combine forage yield and digestibility into a single value in which yield and digestibility are equally weighted. Nine accessions had index values greater than 1.0. By comparison, the nursery mean NI value was 0.0 and Jose and Platte had NI values of 0.79 and 2.21 , respectively. Three accessions, PI 98526, PI 264770, and PI 410007, had NI values greater than the NI value of either check cultivar. In addition to having high yields and high IVDMD, these accessions also were equivalent to the check cultivars in other agronomic traits as indicated by high leafiness and inflorescence number scores. The accessions with NI values greater than 2.0 should be valuable to plant breeders for attempting to improve forage digestibility and quality of tall wheatgrass.

Platte and three other tall wheatgrass cultivars trace primarily to PI 98526 . Platte was significantly lower in first harvest IVDMD than PI 98526 (Table 1). In previ- ous breeding work with tall wheatgrass, forage quality, other than leafiness, was not a selection criterion. These results indicate that in the development of Platte, forage quality as measured by IVDMD may have been adversely affected. Since forage digestibility was not used as a selection criterion by the breeders who developed Platte, Alkar, Orbit, and NE 98526 from PI 98526 and because PI 98526 had the highest IVDMD of any of the tall wheatgrasses evaluated, the potential for developing a tall wheatgrass cultivar with improved IVDMD from PI 98526 is very high.

First harvest forage yield ( $\mathrm{H} 1)$ and first harvest forage IVDMD were positively correlated although the correlation was low (Table 2). Second harvest (H2) forage yield also was positively correlated with first harvest forage yield. Plant height, leafiness, and inflorescence scores were correlated positively to forage yield. Traits that were correlated positively with IVDMD were leafiness and inflorescence number scores, heading date, second harvest IVDMD, and yield. Neither forage yield or IVDMD for either harvest were correlated with forage protein concentration. First and second harvest for-

Table 2. Correlations of selected traits of tall wheatgrass with first harvest forage yield (H1), and first harvest forage in vitro dry matter digestibility (IVDMD H1) and protein concentration.

\begin{tabular}{|c|c|c|c|}
\hline Trait $_{\dagger}$ & Forage yield & IVDMD H1 & Protein H1 \\
\hline IVDMD H1 & $0.37 * *$ & & \\
\hline Protein H1 & 0.01 & -0.05 & \\
\hline Yield H2 & $0.38 * *$ & (0.33* & 0.16 \\
\hline IVDMD H2 & $0.66^{* *}$ & $0.29 *$ & -0.04 \\
\hline Protein $\mathrm{H} 2$ & 0.21 & 0.04 & $0.77^{* *}$ \\
\hline Heading date & 0.00 & 0.35* & $-0.62 * *$ \\
\hline Height & $0.47 * *$ & 0.06 & $-0.44 * *$ \\
\hline Inflorescence score & $0.58 * *$ & $\mathbf{0 . 4 3} * *$ & $-0.28^{*}$ \\
\hline Leaf abundance score & $0.84 * *$ & $0.41 * *$ & 0.15 \\
\hline
\end{tabular}

$* ; * ;$ indicate significance at the 0.05 and 0.01 levels of probability, respectively $(\mathrm{df}=\mathbf{5 0}$ ).

$\dagger \mathrm{H1}$ is first forage harvest, $\mathrm{H} 2$ is regrowth harvest. 
age protein concentrations were positively correlated. These correlations indicate that it should be feasible to simultaneously improve forage yield and digestibility in a tall wheatgrass breeding program. It may be possible to improve forage protein concentration if selection pressure also is applied for that trait. Although seed production was not measured, the positive correlations of inflorescence number with forage yield and IVDMD indicate that it should be possible to improve these traits while maintaining or improving seed yields.

In summary, several of the PI lines had forage yields equivalent to the check cultivars and had first harvest IVDMD values equivalent or higher than the check cultivars. In addition to having high yields and high IVDMD, these accessions also are equivalent to the check cultivars in other agronomic traits as indicated by high leafiness and inflorescence scores. Our results indicate that superior germplasm exists in the USDA tall wheatgrass germplasm collection that can be used to develop improved cultivars of tall wheatgrass with improved forage quality and other agronomic traits. PI 98526 will continue to be an important source of germplasm for improving tall wheatgrass. Additional collections in the region where PI 98526 was originally collected, near the Saratov Institute for the Study of Drought in the former USSR, would be valuable.

The data from this study has been entered into the Germplasm Resources Information Network (GRIN) database of the USDA-ARS which is available for public access at the internet address: http://www.ars-grin. gov/npgs/. Ten additional germplasm accessions of tall wheatgrass have been added to USDA germplasm collection since this study was initiated.

\section{REFERENCES}

Association of Official Analytical Chemists. 1980. Official methods of analysis. 13th ed. AOAC, Washington, DC.
Alderson, J., and W.C. Sharp. 1994. Grass varieties in the United States. USDA-SCS Agric. Handb. 170. U.S. Gov. Print. Office, Washington, DC.

Asay, K.H., and K.B. Jensen. 1996. Wheatgrasses. p. 691-724. In L.E. Moser et al. (ed.) Cool-season forage grasses. Agron. Monogr. No. 34 ASA, CSSA,SSSA, Madison, WI.

Barkworth, Mary E., and D.R. Dewey. 1985. Genomically based genera in the perennial triticeae of North America: identification and membership. Am. J. Bot. 72:767-776.

Conard, E.C., and D.C. Clanton. 1963. Cool-season, warm-season pastures needed. p. 11-13. In Beef Cattle Progress Report, Animal Husbandry Department, College of Agriculture, University of Nebraska, Lincoln, NE.

Lamb, J.F.S., K.P. Vogel, and P.E. Reece. 1984. Genotype and genotype $X$ environment interaction effects on forage yield and quality of crested wheatgrass. Crop Sci. 24:559-564.

Marten, G.C., and R.F Barnes. 1980. Prediction of energy digestibility of forages with in vitro rumen fermentation and fungal enzyme systems. p. 61-71. In W.J. Pigden et al. (ed.). Standardization of analytical methodology for feeds. Rep. IDRC-134e, International Development Centre, Ottawa, Canada.

Rumery, M.G.A., R.E. Ramig, and B.R. Somerhalder. 1964. Irrigated bromegrass, intermediate, and tall wheatgrass pastures for dairy cows. S.B. 484. College of Agric. \& Home Econ., and the Agric. Exp. Stn., Univ. Nebraska, Lincoln, NE.

Schutz, W.M., and C.C. Cockerham. 1966. The effect of field blocking on gain from selection. Biometrics 22:843-863.

Steel, R.G.D., and J.H. Torrie. 1980. Principles and procedures of statistics: A biometrical approach. 2nd ed. McGraw-Hill Book Co., New York.

Vogel, K.P. 1980. Evaluation of intermediate wheatgrass for use in a breeding program. USDA/SEA-AR, ARR-NC-4 (USDA research bulletin).

Vogel, K.P. 1983. Evaluation of the bromegrass introductions for forage yield and quality. Nebr. Agric. Exp. Stn. Res. Bull. 300.

Vogel, K.P., P.E. Reece, and J.F.S. Lamb. 1986. Genotype and genotype $\times$ environment interaction effects for forage yield and digestibility of intermediate wheatgrass. Crop Sci. 26:653-658.

Windham, W.R., D.R. Mertens, and F.E. Barton II. 1989. Protocol for NIRS calibration: Sample selection and equation development and validation. p. 96-103. In G.C. Marten et al. (ed.). Near infrared reflectance spectroscopy (NIRS): Analysis of forage quality. USDA Agric. Handb. 643.

Zhang, X., Dong, Y. and Wang, R.R.C. 1996. Characterization of genomes and chromosomes in partial amphiploids of the hybrid Triticum aestivum $\times$ Thinopyrum ponticum by in situ hybridization, isozyme analyses, and RAPD. Genome 39:1062-1071. 